\title{
ビデオを利用した視能矯正シミュレーション教材の試作
}

\author{
難波 哲子・深井小久子・早川 友恵 \\ 1) 川䗁医療福祉大学医療技術学部感覚矯正学科 \\ 2) 川崎医科大学眼科学教室
}

\section{New Educational Videos for Student Orthoptists}

\author{
Tetsuko Namba, Sakuko Fukai, Tomoe Hayakawa \\ 1) Department of Sensory Sciences Faculty of Medical Professions, Kawasaki University of Medical Welfare \\ 2) Department of Ophthalmology Kawasaki Medical School
}

要 約

即物的学習が求められる視能矯正の実習教育は，臨床現場が最適であるが, 種々の制約があるた めに满足できる状態ではない。そこで, 教育目標に沿った視能矯正シミュレーション教材をビデオ で作成し，実習に応用して教育的効果と受容度について検討を行った。

視能矯正実習の教育目標およびビデオの内容は， 2 年次では視能訓練士に必要な基本的態度とマ ナーの例, 3 年次では臨床的技能と方法を発展, 応用するための視覚障害シミュレーション, 4 年 次では問題解決能力を養成するための視能矯正管理ロールブレイである。

学生によるアンケート調査の結果, ビデオを利用したシミュレーション教材は受容度が高く, 臨 床応用が可能で教育的効果があり, 視能矯正実習における有意義な教育方法であるという評価が得 られた。

\section{Aisstract}

It is necessary for student orthoptists to be trained in a clinical setting as much as possible. However, there is not enough practical training due to various limitations. To supply the lack of real situations, educational simulation videos have been produced. The videos were shown during classes at our school and the usefulness of the videos as an educational tool was evaluated through a questionnaire given to the students.

The video library consists of three different topics for each academic year. These topics are "basic attitude toward clients and manner in the clinic" for the second year students, "knowledge and techniques of orthoptic training for visual disturbance" for the third year students, and "role playing for orthoptic management based on the problem oriented system" for the fourth year students.

This study concludes that the new educational videos are very useful as a part of orthoptic training and accepted by students with interest.

連絡先（T701-01）倉敷市松島288

川崎医療福祉大学感覚矯正学科 難 波 哲子

Tel. 086-462-1111 内線4920, 4632

Key words : orthoptics, education, simulation, role playing, video 


\section{I . 目 的}

即物的学習が求められる視能矯正の実習教育 は, 臨床現場で行うことが最適であるが, 種々 の制約があるために満足できる状態ではない。 私どもは, 視能矯正の実習教育に臨床例を参考 にしたロールプレイ，シミュレーションなどの 実習教育を展開している1２２３）1。

一方, 医学教育においては, AV (Audiovisual) 教材やCAI (Computer Assisted Instruction）教材を使用した症例シミュレーシ ヨン演習が行われている ${ }^{5)}$ 6)。また，よく工夫 された視聴覚教材は, 実習補助教材として利用 すると学習効果が向上する7)。

今回, 私どもは教育目標に沿った視能矯正シ ミュレーション教材をビデオで作成し, 実習に 応用して教育的効果と受容度について検討を行 った。

\section{II . 対象および方法}

\section{1) 対象}

ビデオ教材を用いて授業を行った対象は，川 崎医療福祉大学感覚矯正学科視能矯正専攻 2 年 次 28 名, 3 年次 26 名, 4 年次 30 名の学生である。

\section{2 ) 実習の教育目標}

視能矯正学実習の教育目標は, 2 年次では視 能訓練士に必要な基本的態度とマナーを身につ ける。 3 年次では臨床的技能と方法を発展させ 応用能力をつける。 4 年次では患者の問題点を 正しくとらえて, 問題解決能力を養成するに設 定している。

\section{3) 実習の形式}

ビデオによる実習は，2 年次は病院実習開始 直前に 1 コマ 90 分を 1 回， 3 年次は病院実習開 始前に 2 コマ 180 分を 1 回と 1 回が30分の臨床例 のロールプレイを 12 回， 4 年次は学外病院実習 開始前に 2 コマ180分を 2 回実施している。

\section{4 ) ビデオ教材の内容}

教材の内容は, 2 年次では病院実習における 態度およびマナー教育， 3 年次では高齢化によ る視覚障害シミュレーションと臨床例（12症例） のロールプレイ， 4 年次では視能矯正管理ロー ルプレイである。

\section{5 ) 教材の作成}

ビデオ教材は, 企画, 原稿作成, 台本作成, 撮影および編集などを通して完成した（図 1 ）。 2,3 年次用のビデオ教材は, シミュレーショ ンしている場面を撮影した後, 編集して学生に 供覧した。ロールプレイについては初演と再演 を供覧した。 4 年次用の教材は，視能矯正管理 の課題を呈示して学生が視能訓練士, 模擬患者 およびその家族の役になりロールプレイを行っ た。ロールプレイの進行は実症例に即した状況 設定をして，問診聴取あるいはインフォームド コンセントを行って，コミュニケーションをと っている様子をビデオに収録した（図 2 )。第

\section{ビデオ教材の作成順序}

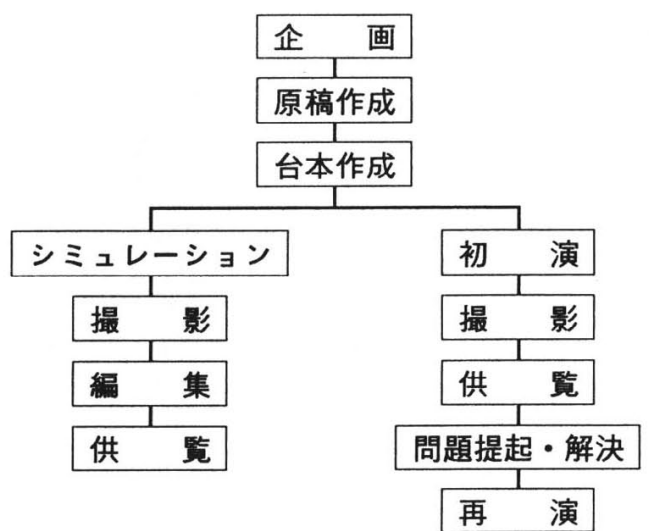

図 1 ビデオ教材の作成順序

2,3 年次用は企画 $\rightarrow$ シュレーション $\rightarrow$ 供覧, 4 年次用は企画 $\rightarrow$ 初演 $\rightarrow$ 再演

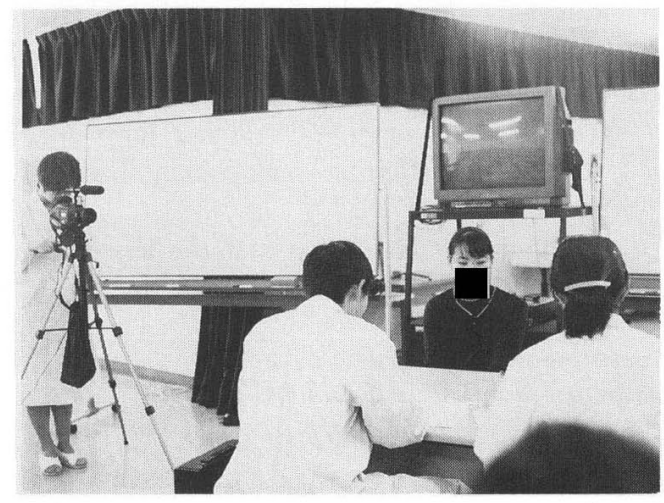

図 2 ビデオを利用した視能矯正実習の場面 
1 回目のロールプレイをビデオで撮影・再生し て学生に供覧した後, 問題提起および問題解決 方法を討論して, 第 2 回目のロールプレイをビ デオで撮影した。

\section{6 ) 教材の評価}

ビデオ教材を供覧後, 2 年次の学生を対象に アンケート調查を行った。アンケートの内容は 「ビデオ教材による実習について」,「教育の効 果について」，「授業の感想について」である (図 3 )。ビデオ教材の教育的効果については, 授業の理解度, 臨床への応用, 問題解決能力の 向上および自己学習への動機づけの程度などに ついて,「はい」「ふつう」「いいえ」の 3 段階 にわけて, 評価を行った。

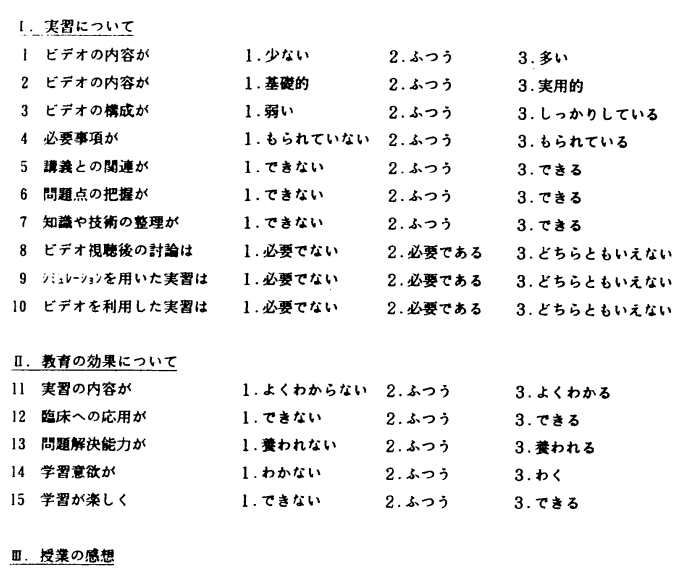

図 3 ビデオを利用した視能矯正実習に 対する学生へのアンケート

\section{III. 結 果}

\section{1 ) 実習内容からみたビデオ教材}

2 年次では, 病院実習開始前に, 病院実習に おける態度およびマナーについて, 学生の有志 が，実習中特に注意を要する集合時間，検査説 明, 守秘義務, エレベーターの中および連絡方 法の 5 場面のシミュレーションを行った。これ らをビデオに収録して編集した後，学生に供覧 した。ビデオ視聴後, 学生が病院実習の目的, 心構えなどについて討論を行ったところ, 病院 実習にふさわしい態度やマナーについて活発な 意見が出され，実習に対する動機づけができた。
また，ビデオ教材は医療専門職としての態度教 育にも役立つことが，学生の感想，アンケート， 態度などから考えられた。

3 年次では, 種々の視機能疾患を想定したシ ミュレーション实習を行った。その一つとして， 高齢者疑似体験セット「うらしま太郎」(社団 法人 長寿社会文化協会) を用いた実習を行っ た。日常生活での高齢者の不便さを描いたビデ オを視聴後, 装具をつけた。足首に重り, 㯟や 时にサポーター, 眼には白内障による色覚変化 や視野狭窄を実感できる特殊眼鏡, 耳を聞こえ にくくする耳栓をつけ，75～80歳代の高齢者の 身体的機能低下や心理的変化を体験した。学生 が実際に装具をつけ, 高齢者の不自由さを実感 している様子をビデオに収録して編集した後， 学生に供覧した。

3,4 年次では, 視能矯正管理が必要な症例 のロールプレイ実習を行った。学生が模擬患者, 患者の親, 視能訓練士のそれぞれの役を決め状 況設定をして, 約15分間のロールプレイを行っ た。第 1 回目のロールプレイをビデオで撮影・ 再生して学生に供覧した。ビデオで確認した後, グループ討議を通じて問題点の発見および問題 点の解決を行い, 第 2 回目のロールプレイを行 った。その後, 症例の問診聴取, 問題点, 検査 計画, 検査結果, 問題点の抽出, 治療・訓練計 画などについてのまとめを行った。ビデオによ るロールプレイ実習では, 学生は授業に積極的 に参加でき，実際的で役に立つという賛成意見 の他に，緊張感が続く，ノートがとりにくいな どの意見が得られた。

\section{2 ) ビデオ教材の評価}

教材の評価はビデオを視聴直後, 実習および 教材に対するアンケート調査を 2 年次生 28 名に 実施した。教育的効果を評価するため, 実習の 内容, 臨床への応用, 問題解決能力の向上, 学 習意欲, 学習が楽しいについて，「できる」ま たは「わかる」という肯定的な答を 2 点,「ふ つう」を 1 点,「できない」または「わからな い」という否定的な答を 0 点として集計した。 その結果，5つのいずれの質問にも否定的な答 はなく，「ふつう」または肯定的な答えであっ た。ビデオ実習の内容については, 実習が少な 
いため得点は 3 であったが，その他の項目では すべて得点は 4 であった。教育的効果について 総合評価すると, 肯定的な答「A」は半数以上 の $55 \%$ ，ふつうの「B」は45\%，否定的な答「C」 は $0 \%$ あ゙った。したがって，ビデオを用いた シミュレーション教材は, 学生の受容度が高く 教育的効果に優れていることがわかった(表 1$)$ 。

「実習について」の項のアンケート結果をま とめると, 必要事項が満たされている, 問題点 の把握ができる，という肯定的な意見が多かっ た。またシミュレーションやビデオを用いた実 習に賛成している学生も多かった。「授業の感 想」としては，文章で内容を示すよりも具体的 でわかりやすい，客観的に見ることにより，気 づくことや確認できる点がある，言葉だけでな く，映像を見ることで強い印象を受けるという 意見があった。

\section{表 1 学生によるビデオ教材の評価}

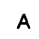

B

C

得点

\section{実習内容の理解}

臨床への応用

問題解決能力

学習意欲

学習が楽しい

7 名 (25\%) 21名(75\%) 0 名 $(0 \%) \quad 3$

19名 (68\%) 9名 (32\%) 0 名 (0\%) 4

16名(57\%) 12名 (43\%) 0 名 ( $0 \%)$

15名 (54\%) 13名 (46\%) 0 名 ( $0 \%)$

20 名 $(71 \%) \quad 8$ 名 $(29 \%) \quad 0$ 名 $(0 \%)$

総 合

15名(55\%) 13名(45\%) 0 名 (0\%)

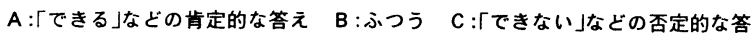

\section{IV. 考按}

ビデオを利用したシミュレーション教材を作 成し, 実習に応用して, 教育的効果と受容度に ついて検討を行った。ビデオを利用したシミュ レーション教材の利点は, 同一教材で同時に多 人数の学習が可能であり, 反復学習および自学 自習に有効な手段である。また，知識や経験を 蓄積することが可能であり, 問題解決能力を養 成して, 臨床現場で役立つことがあげられる。 優れている点は, 教科書や講義で学ぶ内容と比 べて, 臨場感, 説得力, 迫力が異なるため, 医 学教育における補助教材としての意義は大きい 7)。さらに，教師自身が教育目的とする教材を
作成することにより，授業のアウトラインを学 生につかませ, 学生全体の理解を一定のレベル にあげて授業への取り組みができ, 教育効果が 上がることが考えられる。学生が興味を示す教 材を呈示することは, 学習効果の向上に役立つ が，これにはビデオ映像による動画が最適であ る。

4 年次生を対象とした視能矯正管理ロールプ レイの実習にビデオを利用した。コミュニケー ション技法の教育には, ビデオによる撮影, 供 覧および討論は, 教育的効果が期待できるが時 間と費用がかかる ${ }^{8)}$ 。また, 実症例による体験 とは異なるため, 学生の捉え方は表面的になら ざるをえないという欠点もある。さらに，実習 の内容を強調するには, 相応の画面の工夫を必 要とするため, 問題点としては, ビデオの企画 および編集に時間と労力を要し, 機器の利用と 環境の完備が必要なことである。教育には人間 的接触が不可欠であり，ビデオを基礎として教 貝と学生が話し合いをしながら実習をしてはじ めて，教育が成立すると考えられるため，ビデ オを実習の一部として用いるときに意義がある 9)。

ビデオを利用した教材は, 学生によるアンケ 一ト評価において，教育的効果と受容度が高い ため，今後，実習内容に即したビデオ教材を作 成し, 活用して教育効果を向上させる方法とし て有用であると考えられる。

医学教育においてシミュレーション教育, $\mathrm{AV}$ 機器・コンピュータを活用した教育法の研 究が報告されている ${ }^{91}{ }^{10)}$ 。21世紀の教育は， マ ルチメディア社会に対応した教育が必要とされ ているが, 視能矯正学においても, 問題解決能 力の向上のために，マルチメディア利用の双方 向的な教育システムおよび新しい教育技法の開 発が必要であると考える。

今後, 評価法はビデオ内容を理解して, シミ ユレーションした状況において問題を解決する 能力を客観的に測定する試験形式を考える必要 がある ${ }^{11) 。}$

\section{V. 結 論}

ビデオを利用したシミュレーション教材は， 
臨床応用が可能で教育的効果があり, 視能矯正 実習における有意義な教育方法である。したが って, 病院実習開始前に本法を用いて実習を行 うことが有用である。

稿を終えるにあたり，御校閲賜りました川崎 医科大学眼科学教室田淵昭雄教授に深謝致しま す。

本研究の一部は平成 7 年度川崎医療福祉大学 プロジェクト研究費によったことを付記して感 謝の意を表します。

\section{文献}

1）難波哲子, 深井小久子 他：シミュレーショ ンを利用した視能矯正実習教育の試み。日本 視能訓練士協会誌, $23: 138-143,1995$.

2 ）深井小久子, 早川友恵, 難波哲子: 視能矯正 学における面接ロールプレイの活用. 眼臨, $89: 1413-1417,1995$.

3 ）難波哲子, 早川友恵, 深井小久子: 学術展示 ポスター演習による実習教育の試み.日本視 能訓練士協会誌, $22 ： 34-38,1994$.

4 ）深井小久子, 早川友恵, 難波哲子 他：チ工 ックリストによる実習教育の評価. 眼臨, 88 :929-932, 1994.

5 ）堀 原一, 眞崎知生 他: AV教材とCAI教材 を効果的に取り入れた新しい医学教育カリキ ユラムの構築. 医学振興財団昭和 63 年度医学 教育研究助成成果報告書 : 80-91. 1990.

6) 日本医学教育学会教育開発委員会編: 医学教 育マニュアル 5 . シミュレーションの応用, 篠原出版, 東京, 1984.

7 ）星野一正：シミュレーション.日本医学教育 学会教育技法委員会編, 医学教育技法マニュ アル，250-254，篠原出版，東京，1993.

8 ）津田 司：コミュニケーション技法教育の実 際. 日本医学教育学会教育技法委員会編, 臨 床教育マニュアル, 208-214, 篠原出版, 東 京, 1994.

9 ）酒井克弘, 大場正巳 : ビデオによる卒前・卒 後医学教育の現状. 医療とコンピュータ.
$4: 39-43.1992$.

10）松山敏剛, 山本博道 他：スチルビデオシス テムを使用した医学教育用シミュレーション の試作とその使用経験. 医学教育. $24: 215-$ 219. 1993.

11）日本医学教育学会教育開発委員会編：医学教 育マニュアル 1 . 医学教育の原理と進め方, 篠原出版, 東京, 1990 .

質問 (平和学院衛生福祉専門学校 小倉 洋子) 1. 診療施設のない養成校として, 興味をもって ビデオを拝見しましたが, 次の点についてご 教示下さい。

(1)企画から制作, 編集まで, 時間と労力のい ることだと思いますが, 出来映えがすばらし いので, 撮影と編集をどなたが行っていらっ しゃるのでしょうか。

(2)ビデオの中にありました高齢者体験セット について,これはどのようにして購入できる のでしょうか。また価格についてもわかりま したら教えて下さい。

(3)本来, 自分たちで作成すべきものだと思い ますが, 安易なお願いですがこのような教材 を, 私どもでも利用させていただく教育教材 として作成される予定がありますでしょうか。

\section{答弁}

1. (1)ビデオの撮影および編集は, 教員あるいは 大学院生が行っています。大学院生は, 実技 実習指導法を学ぶ目的で行っています。 (2)高齢者疑似体験セット「うらしま太郎」は, 1 セット 20 万円, 解説ビデオは 1 本 5 千円で す。提供は社長寿社会文化協会が行っていま す。研修を受けインストラクターの資格者が いて使用するか, 又は, 協会の会員となって 使用できます。

(3)教材として, 現在 4 年次の視能矯正管理口 ールプレイを撮影したビデオが12例あります。 御希望がありましたら，教材としてお使いい ただくことを検討させていただきます。 